Volume 1, Nomor 1, Maret 2019, pp 15-30. Copyright (C) 2019 JAFTA, Program Studi Magister Akuntansi, Fakultas Ekonomi, Universitas Kristen Maranatha. ISSN: 2654-4636| E-ISSN: 2656-758X

http://journal.maranatha.edu/Jafta

\title{
Pengaruh Pengendalian Internal dan Komitmen Organisasi Terhadap Kualitas Pelaporan Keuangan (Survei pada Perusahaan Tekstil di Kota Bandung dan Sekitarnya)
}

\author{
Rinie \\ Universitas Kristen Maranatha \\ rini@yahoo.com \\ Vincent Mak Pranata \\ Universitas Kristen Maranatha \\ dcent0512@gmail.com \\ Rapina \\ Universitas Kristen Maranatha \\ rapinacen@yahoo.com
}

\begin{abstract}
In fact there are stillproblems with poor government financial reporting. This is indicated by financial management problems due to weak internal control and non-compliance with laws and regulations. Thisissue become interesting to investigate because it is a thing that often happens in Indonesia. This study aims to examine the effect of internal control and organizational commitment to the quality of financial reporting. The population in this study is the accounting or finance staff in the company of Bandung and surrounding using a type of research that is explanatory research. The sampling technique in this research is non probability sampling with purposive sampling procedure, sample of this research is all staff accounting or finance in PT X and PT Gistex Textile Division. The data have been obtained will be processed using SPSS 20. This study uses a model of multiple linear regression analysis model to test the effect of internal control and organizational commitment to financial reporting quality. The results showed that internal control affects the quality of financial reporting, while organizational commitment has no effect on the quality of financial reporting.
\end{abstract}

Key words: Internal Control, Organizational Commitment, Financial Reporting Quality.

\begin{abstract}
ABSTRAK
Merupakan sebuah fakta bahwa masih terdapat banyak masalah mengenai kualitas pelaporan keuangan pemerintah yang buruk. Hal ini diindikasikan oleh masalah-masalah yang ada pada manajemen keuangan yang disebabkan oleh lemahnya pengendalian internal dan ketidakpatuhan terhadap hukum dan peraturan yang berlaku. Masalah ini menjadi menarik untuk diteliti karena merupakan hal yang sering terjadi di Indonesia. Tujuan dari penelitian ini yaitu untuk menguji pengaruh dari pengendalian internal dan komitmen organisasi terhadap kualitas pelaporan keuangan. Populasi dalam penelitian ini adalah stafaccounting atau finance di perusahaan yang berada di wilayah Bandung dan sekitarnya dengan menggunakan jenis penelitian explanatory. Teknik pengambilan sampel pada penelitian ini menggunakan non probablity sampling dengan prosedur purposive sampling, sampel dari penelitian ini adalah
\end{abstract}


seluruh staf bagian accounting atau finance di PT X dan PT Gistex Textile Division. Data yang telah didapatkan kemudian diproses dengan menggunakan bantuanperangkat lunakSPSS 20. Penelitian ini menggunakan model analisis regresi linier berganda untuk menguji pengaruh dari pengendalian internal dan komitmen organisasi terhadap kualitas pelaporan keuangan. Hasil penelitian ini menunjukkan bahwa pengendalian internal berpengaruh signifikan terhadap kualitas pelaporan keuangan, sementara komitmen organisasi tidak berpengaruh signifikan terhadap kualitas pelaporan keuangan.

\section{Kata kunci: Pengendalian Internal, Komitmen Organisasi, Kualitas Pelaporan Keuangan.}

\section{PENDAHULUAN}

\subsection{Latar Belakang}

Akuntansi merupakan bahasa bisnis, hal ini menjadikan bahwa semakin baik dalam memahami bahasa tersebut maka akan semakin baik dalam mengelola bisnis. Hal tersebut dipertegas bahwa setiap organisasi menggunakannya sebagai bahasa komunikasi saat berbisnis, seperti saat terjadi pertukaran barang dengan sejumlah uang (Azhar Susanto, 2008). Informasi Akuntansi merupakan hasil suatu proses akuntansi yang meliputi proses pengindentifikasian, pengukuran, analisis dan pengkomunikasian data-data keuangan. Penyajian informasi akuntansi secara umum disajikan dalam bentuk laporan laporan keuangan. Informasi akuntansi yang disajikan dalam bentuk laporan bisa dipergunakan sebagai dasar pengambilan keputusan, maka informasi akuntansi harus berkualitas. Selanjutnya Hilton et al (2000) menjelaskan bahwa informasi akuntansi yang berkualitas harus memenuhi tiga karakteristik yaitu relevan, akurat, tepat waktu.

Forum Indonesia untuk Transparansi Anggaran (FITRA), menyatakan negara mengalami kerugian lebih dari Rp 221,8 triliun dari APBN P 2015 (Firmansyah, 2016). Kerugian ini diduga disebabkan oleh buruknya aspek pencatatan keuangan dan belum disiplinnya sistem penegakan penerimaan sanksi oleh negara.Menurut Pratomo (2013) saat ini masih terdapat 10 Kementerian/Lembaga yang memiliki kualitas laporan keuangan yang buruk.

Fenomena buruknya laporan keuangan di Kementrian/Lembaga pemerintahan seperti yang dikatakan BPK (2015) ini disebabkan karena belasan ribu permasalahan dalam pengelolaan keuangan pemerintah. Sementara itu, berdasarkan jenis pemeriksaannya yang terdiri atas 607 pemeriksaan keuangan, 5 pemeriksaan kinerja, dan 54 pemeriksaan dengan tujuan tertentu. Dari pemeriksaan tersebut ditemukan sebanyak 10.154 temuan yang memuat 15.434 permasalahan yang meliputi 7.890 atau 51,12 persen permasalahan ketidakpatuhan terhadap ketentuan peraturan perundang-undangan senilai $\mathrm{Rp33,46}$ triliun dan 7.544 atau 48,88 persen permasalahan kelemahan sistem pengendalian intern.

Permasalahan kualitas informasi akuntansi pada lembaga-lembaga keuangan maupun negara masih banyak hal ini bisa dilihat dari beberapa fenomena yang di kemukakan oleh 
para ahli diantaranya yang dikemukan oleh mantan Ketua Badan Pemeriksa Keuangan (BPK), Anwar Nasution (2009) mengemukakan bahwa kualitas laporan keuangan pemerintah daerah (LKPD) semakin memburuk. Deputi Gubernur Bank Indonesia, Budi Mulya (2010) menambahkan bahwa bank dituntut untuk lebih transparan dan jujur dalam melaporkan neracanya. Selain itu Deputi Gubernur Bank Indonesia, Budi Rohadi, menyatakan bahwa masih banyak bank-bank kecil melakukan manipulasi laporan keuangan (windows dressing) dan untuk bank-bank besar masih ada juga yang melakukan manipulasi laporan keuangan (windows dressing). Ketua Perhimpunan Bank-Bank Umum Nasional yaitu Sigit Pramono (2010) mengemukakan kembali bahwa dalam kasus Bank Century, bank tersebut tidak akurat dalam melaporkan kondisi perusahaannya.

Dari fenomena di atas, dapat diketahui bahwa pengelolaan laporan keuangan pemerintah masih buruk.Menurut Standar Akuntansi Keuangan (2015) laporan keuangan adalah suatu penyajian terstruktur dari posisi keuangan dan kinerja keuangan. Tujuan laporan keuangan adalah memberikan informasi mengenai posisi keuangan, kinerja keuangan, dan arus kas entitas yang bermanfaat bagi sebagian besar pengguna laporan keuangan dalam pembuatan keputusan ekonomik. Laporan Keuangan merupakan bagian dari proses pelaporan keuangan.

Fenomena lainnya banyak disampaikan oleh para pakar lainnya tidak hanya pada lembaga keuangan tetapi pada lembaga pemerintah. Hal tersebut dikemukakan oleh
Gamawan Fauzi (2011) yang menjabat sebagai Menteri Dalam Negeri, bahwa kendati kualitas laporan keuangan sektor publik, terutama didaerah mengalami peningkatan tetapi kami menilai dari sisi pengelolaan dan pelaporan keuangan daerah masih banyak Kelemahannya. Selanjutnya Hendrisman Rahim (2013) mempertegas bahwa pada perusahaan perasuransian di Indonesia berkaitan dengan belum adanya petunjuk teknis sistem pelaporan kuangan sehingga sebagian besar perusahaan asuransi terkendala dalam menerapkan standar akuntansi internasional atau International Financial Reporting Standar (IFRS).

Berdasarkan fenomena yang ada, buruknya laporan keuangan disebabkan oleh lemahnya pengendalian internal dan ketidakpatuhan terhadap peraturan perundangundangan. Pengendalian internal adalah proses yang dijalankan oleh dewan komisaris, manajemen dan personel lain entitas yang didesain untuk memberikan keyakinan memadai tentang pencapaian tujuan (Tunggal, 2010).Selain pengendalian internal, buruknya laporan keuangan juga disebabkan oleh ketidakpatuhan terhadap peraturan perundangundangan. Sugandi (2013) mengatakan bahwa dengan adanya komitmen organisasi akan mempertahankan kepatuhan dalam penyajian laporan keuangan sehingga dapat meningkatkan kualitas keandalan laporan keuangan. Komitmen organisasi adalah sikap yang mewakili sejauh mana seorang karyawan mengidentifikasi dengan organisasinya dan keinginan untuk tetap menjadi anggota organisasi (Baldwin, 2013). 
Dalam penelitian sebelumnya, Komarasari (2017) mengungkapkan bahwa pengendalian internal berpengaruh signifikan terhadap keandalan pelaporan keuangan.Rosalin (2011) mengungkapkan bahwa komitmen organisasi berpengaruh postif terhadap keandalan pelaporan keuangan. Penelitian ini merujuk pada penelitian terdahulu yang dilakukan oleh Sugandi (2013) mengenai Pengaruh Kapasitas Sumber Daya Manusia, Pemanfaatan Teknologi Informasi, Pengendalian Intern Akuntansi, dan Komitmen Organisasi Terhadap Keterandalan Pelaporan Keuangan Pemerintah Daerah (Survei Pada SKPD se-Kabupaten Kuansing).

Berdasarkan paparan yang sudah dijelaskan, peneliti akan melakukan penelitian yang berjudul "PENGARUH PENGENDALIAN INTERNAL DAN KOMITMEN

\section{ORGANISASI TERHADAP KUALITAS PELAPORAN KEUANGAN"}

\subsection{Rumusan Masalah}

Berdasarakan latar belakang penelitian di atas maka rumusan maslah pada penelitian ini adalah:

1. Seberapa besar pengendalian internal berpengaruh terhadap kualitas pelaporan keuangan.

2. Seberapa besar komitmen organisasi berpengaruh terhadap kualitas pelaporan keuangan.

\subsection{Tujuan Penelitian}

Tujuan dari penelitian ini yaitu:

1. Untuk mengetahui apakah pengendalian internal berpengaruh terhadap kualitas pelaporan keuangan.
2. Untuk mengetahui apakah komitmen organisasi berpengaruh terhadap kualitas pelaporan keuangan.

\section{RERANGKA TEORITIS}

\subsection{Kajian Pustaka}

\subsubsection{Pengendalian Internal}

Pengendalian internal adalah suatu proses yang dijalankan oleh dewan komisaris, manajemen, dan personel lain entitas yang didesain untuk memberikan keyakinan memadai tentang pencapaian tiga golongan tujuan berikut ini: (a) keandalan pelaporan keuangan, efektivitas dan efisiensi operasi, dan (c) kepatuhan terhadap hukum dan peraturan yang berlaku (Ikatan Akuntan Indonesia dalam Standar Profesional Akuntan Publik seksi 319 no 69, 2001).Dalam buku Harrer (2008), menjelaskan bahwa manajemen dan dewan direksi dapat menyimpulkan bahwa pengendalian internal efektif jika ada jaminan memadai bahwa tujuan operasional tercapai, laporan keuangan yang dipublikasikan dapat diandalkan dan perusahaan mematuhi undang-undang dan peraturan yang berlaku. Kemudian Azhar Susanto (2008) menyatakan bahwa Pengendalian intern sebagai suatu proses yang dipengaruhi oleh dewan direksi, manajemen, dan karyawan yang dirancang untuk memberikan jaminan yang meyakinkan bahwa tujuan organisasi akan dapat dicapai melalui: (1) efisiensi dan efektivitas operasi, (2) penyajian laporan 
keuangan yang dapat dipercaya, (3) ketaatan terhadap undang-undang dan aturan yang berlaku".

Moeller (2008) mengungkapkan tiga dimensi dari pengendalian internal, yaitu:

a. Keandalan terhadap pelaporan keuangan. Indikator yang digunakan dalam dimensi keandalan pelaporan keuangan adalah bebas dari kesalahan dan dapat diandalkan/dipercaya.

b. Efektivitas dan efisiensi operasi. Indikator yang digunakan dalam dimensi efektivitas dan efisiensi operasi adalah efektif/ukuran pemenuhan output dan tujuan sertra efisien/ukuran penggunaan sumber daya.

c. Kepatuhan terhadap hukum yang berlaku. Indikator yang digunakan dalam dimensi kepatuhan terhadap hukum yang berlaku adalah sesuai dengan hukum yang berlaku di Indonesia dan sesuai dengan peraturan di tempat kerja.

\subsubsection{Komitmen Organisasi}

Komitmen organisasi adalah sikap yang mewakili sejauh mana seorang karyawan mengidentifikasi dengan organisasinya dan keinginannya untuk tetap menjadi anggota organisasi (organizational commitment is an attitude representing the extent to which an employee identifies with his organization and desires to remain a member of the organization) (Baldwin et al, 2013). Komitmen pada organisasi/komitmen organisasional adalah orientasi karyawan terhadap organisasi dalam hal kesetiaan, dan keterlibatan dalam organisasi. Komitmen organisasi didefinisikan sebagai (1) keinginan yang kuat untuk tetap menjadi anggota organisasi tertentu, (2) kemauan untuk mengerahkan usaha yang kuat atas nama organisasi, dan (3) keyakinan yang dalam penerimaan nilai dan tujuan organisasi (Luthans, 2008). Dari penjelasan diatas dapat dikatakan bahwa komitmen organisasi merupakan loyalitas dan keterlibatan karyawan untuk mencapai tujuan organisasi dengan tetap berada dalam organisasi.

Robbins \& Judge (2007) menjelaskan bahwa ada tiga dimensi terpisah untuk komitmen organisasi, yaitu:

a. Komitmen afektif, yaitu sebuah keterikatan emosional terhadap organisasi dan kepercayaan akan nilai-nilainya. Indikator yang digunakan dalam dimensi komitmen afektif adalah keterikatan emosi terhadap organisasi (Kreitner \& Kinicki, 2007) dan setuju dengan tujuan dan nilai organisasi (Greenberg, 2011).

b. Komitmen berkelanjutan, yaitu sebuah keinginan untuk tetap menjadi anggota sebuah organisasi. Indikator yang digunakan dalam dimensi komitmen berkelanjutan adalah 
kesadaran akan biaya yang terkait dengan meninggalkan organisasi

c. Komitmen normatif, yaitu kewajiban untuk tetap didalam organisasi untuk alasan moral atau etika. Menurut Kreitner \& Kinicki (2007) indikator yang digunakan dalam dimensi komitmen normatif adalah merasa berkewajiban melanjutkan pekerjaan.

\subsubsection{Kualitas Pelaporan Keuangan}

Pelaporan keuangan adalah struktur dan proses yang menggambarkan bagaimana informasi keuangan disediakan dan dilaporkan untuk mencapai tujuan pelaporan keuangan yang padagilirannya akan membantu pencapaian tujuan ekonomik dan sosial negara (Suwardjono, 2005).

Wiley (2015) menyebutkan bahwa ada tiga hal yang menunjukkan kualitas pelaporan keuangan yang tinggi yaitu:

a. Kelengkapan (Completeness), yaitu jumlah kewajiban di luar neraca yang signifikan (misalnya, sewa operasi dankontrak pembeliantake-or-pay) harus menjadi perhatian bagi seorang analis karena leverage yang akandilaporkan harus dapat dimengerti.Indikator yang digunakan dalam dimensi kelengkapan adalah kelengkapan informasi (Wiley, 2015) dan keakuratan informasi yang diberikan (Robinson et al 2015).

b. Pengukuran tidak bias (Unbiased Measurement) yaitu aspek penting dari kualitas pelaporan keuangan untuk aset dan kewajiban dengan valuasi secara subjektif. Indikator yang digunakan dalam dimensi pengukuran tidak bias adalah bagian penting dari aset dan bagian penting dari kewajiban.

c. Presentasi yang jelas (clear presentation) yaitu hal-hal yang telah diperinci perusahaan ketika menampilkan laporan keuangan Indikator yang digunakan dalam dimensi presentasi yang jelas adalah rincian yang diperlukan dan informasi yang ringkas dan membantu pemahaman pengguna.
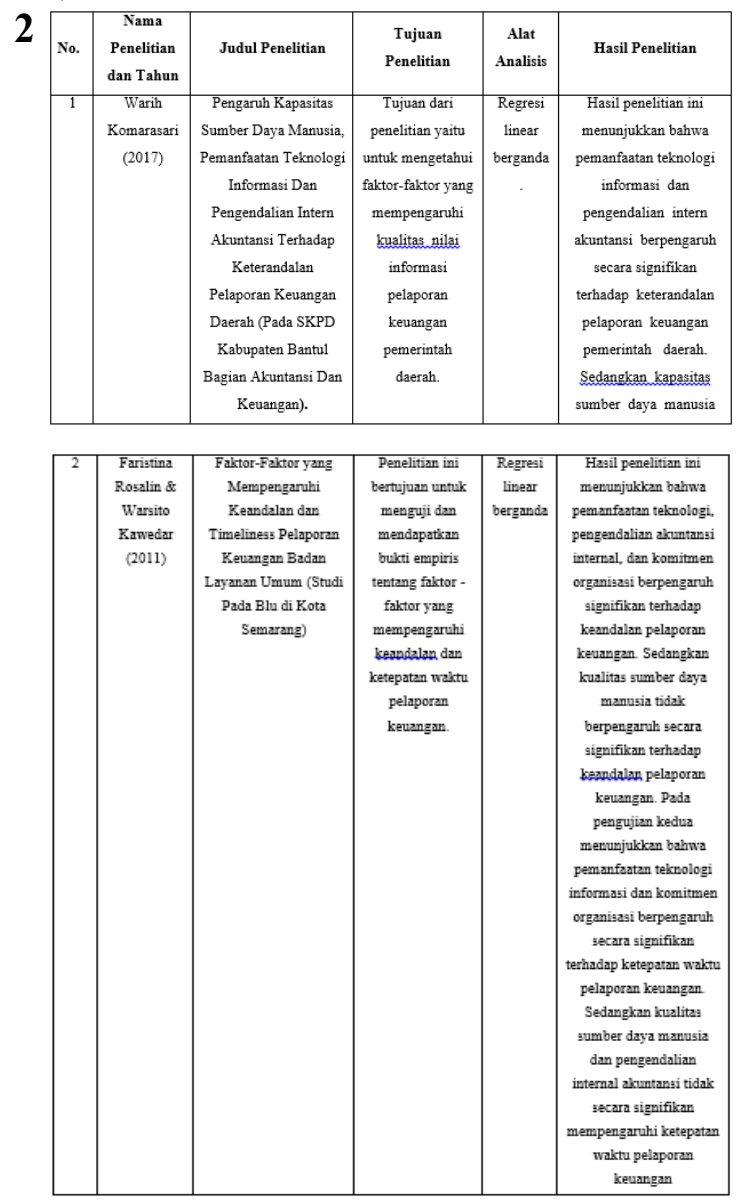


\subsection{Rerangka Pemikiran}

\subsubsection{Pengaruh Pengendalian Internal terhadap Kualitas Pelaporan Keuangan}

Harrer (2008) menjelaskan bahwa pegendalian internal adalah sebuah proses yang dirancang untuk mencapai tujuan pelaporan keuangan yang objektif. Sonnelitter (2008) mengungkapkan bahwa manajemen harus mendekati pengujian pengendalian internal atas pelaporan keuangan dengan cara tunduk pada setiap aspek dari keseluruhan sistem pelaporan akuntansi dan keuangan terhadap pengujian. Seperti diketahui bahwa pengendalian internal atas pelaporan keuangan harus berhubungan dengan setiap bagian dari sistem akuntansi dan pelaporan keuangan, pengujian manajemen harus komprehensif untuk menambahkan semua pengendalian internal yang harus dilaporkan oleh manajemen dan untuk menangani setiap masalah di atas. Perusahaan diharuskan untuk mengembangkan pengendalian intern dengan tujuan untuk memberikan kepastian yang layak bahwa laporan keuangan telah disajikan secara wajar. Sistem informasi akuntansi dan sistem pembukuan (score keeping) tidak akan sukses melaksanakan pengolahan seluruh transaksi akuntansi secara lengkap dan akurat kecuali jika dilakukan pengendalian yang lebih dikenal sebagai pengendalian intern.

Dalam penelitian sebelumnya, Komarasari (2017) mengungkapkan bahwa pengendalian internal berpengaruh signifikan terhadap keandalan pelaporan keuangan.Hal senada juga diungkapkan oleh Darwanis \&
Mahyani (2009) bahwa pengendalian intern akuntansi berpengaruh terhadap peningkatan keterandalan pelaporan keuangan pemerintah daerah.

\subsubsection{Pengaruh Komitmen Organisasi} terhadap Kualitas Pelaporan

\section{Keuangan}

Carsten dan Spector dalam Dodopoet al (2017) mengungkapkan bahwa semakin tinggi komitmen organisasi maka akanberdampak pada karyawan tetap tinggal dalam organisasi dan akan selalu meningkatkan kinerjanya. Hal ini berarti kinerja karyawan yang tinggi akan menghasilkan kualitas pelaporan keuangan yang tinggi.

Dalam penelitian sebelumnya Rosalin \& Kawedar (2011) mengungkapkan bahwa komitmen organisasi berpengaruh positif terhadap keandalan pelaporan keuangan. Hal senada juga diungkapkan oleh Sugandi et al, (2013) bahwa komitmen organisasi berpengaruh signifikan terhadap keterandalan pelaporan keuangan.

\subsection{Pengembangan Hipotesis}

Berdasarkan kerangka pemikiran yang telah diuraikan diatas, maka peneliti memberikan hipotesis sebagai berikut:

Hipotesis I: Terdapat pengaruh pengendalian internal terhadap kualitas pelaporan keuangan 
Hipotesis II: Terdapat pengaruh komitmen organisasi terhadap kualitas pelaporan keuangan

\section{METODE PENELITIAN}

\subsection{Jenis Penelitian}

Jenis penelitian yang digunakan adalah Explanatory research. Explanatory research adalah riset yang mencoba menjelaskan fenomena yang ada (Jogiyanto, 2007).

\subsection{Populasi dan Sampel Penelitian}

dihitung.Makin kecil CV yang dihasilkan, makin baik

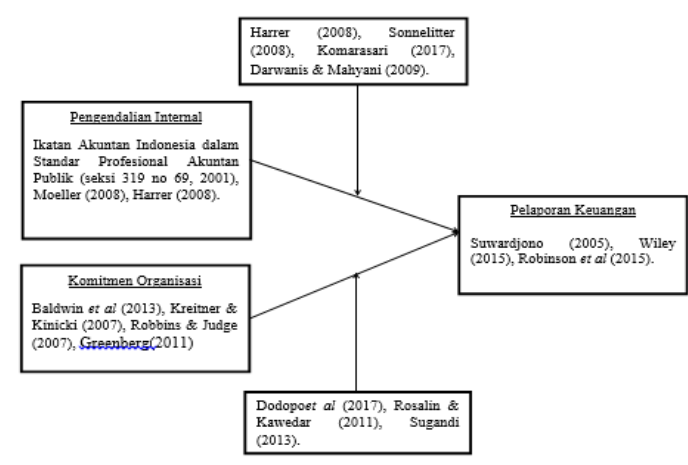

Populasi dalam penelitian ini adalah karyawan yang bekerja di perusahaan tekstil yang berada di Kota Bandung, yaitu PT X dan PT Gistex Textile Division.Teknik pengambilan sampel Non Probability Sampling dengan purposive sampling adapun responden dalam penelitian ini adalah karyawan yang bekerja di Departemen Akuntansi dan Keuangan PT X dan PT Gistex Textile Division.

\subsection{Teknik Pengumpulan Data}

Data yang digunakan dalam penelitian ini adalah data primer, yaitu data yang dikumpulkan sendiri oleh peneliti langsung dari sumber pertama (Suliyanto,2009). Metode yang digunakan untuk mengumpulkan data primer adalah dengan teknik kuesioner (angket).

\subsection{Teknik Analisis Data}

Metode analsis data menggunkan bantuan software SPSS 20, metode analisis data yang digunakan adalah skala likert, uji validitas,uji reliabilitas, uji asumsi klasik yang digunakan adalah normalitas, uji multikolonieritas, uji heteroskedastisitas, pengujian hipotesis yaitu uji regresi linier berganda, koefisien determinasi, dan uji t.

\section{HASIL PENELITIAN DAN PEMBAHASAN}

\subsection{Karakteristik Responden}

Responden dari PT X dan PT Gistex Textile Division berjumlah 35 responden yang terdiri dari 8 Pria dan 27 Wanita. Berdasakan usia, 20 sampai dengan 25 tahun terdiri dari 8 orang, lebih dari 25 tahun terdiri dari 27 orang. Berdasarkan lamanya bekerja, 6 bulan sampai dengan 1 tahun terdiri dari 3 orang, kurang dari 6 bulan terdiri dari 3 orang, lebih dari 1 tahun terdiri dari 29 orang.

\subsection{Uji Validitas dan Reliabilitas}

Berdasarkan hasil penyebaran kuesioner dan penelitian yang dilakukan terhadap 35orang untukvariabel sistem pengendalian internal, komitmen oragnisasi dan kualitas pelaporan keuangan. Dari uji validitas dapat 
disimpulkan bahwa dari 6 butir pernyataan variabel $\mathrm{X} 1$ dengan hasil pengujian keseluruhan pernyataan dikatakan valid. Variabel X2 dengan hasil pengujian ditetapkan 6 butir pernyataan pada variabel komitmen organisasi keseluruhan pernyataan valid. Variabel $Y$ dengan hasil pengujian ditetapkan 6 butir pernyataan pada variabel Kualitas Pelaporan Keuangan keseluruhan pernyataan valid.

\subsection{Uji Asumsi Klasik}

\subsubsection{Uji Normalitas}

Hasil uji normalitas menunjukkan bahwa nilai asymp. sig. yang diperoleh adalah sebesar 0,859. Nilai tersebut lebih besar dibandingkan tingkat signifikansi yang digunakan yaitu 0,05. Berdasarkan kriteria uji normalitas, dapat disimpulkan bahwa distribusi data dinyatakan normal.

One-Sample Kolmogoror-Smirnov Test

\begin{tabular}{|ll|r|}
\hline & & $\begin{array}{r}\text { Unstandardiz } \\
\text { ed Residual }\end{array}$ \\
\hline Nornal & Mean & 35 \\
Parameters,2 & Std. & OE-7 \\
& Deviation & 233358579 \\
Most Extreme & Absolute & .102 \\
Differences & Positive & .096 \\
& Negative & -.102 \\
Kolmogorov-Sminov Z & .604 \\
Asymp. Sig. (2-tailed) & .859 \\
& & \\
\hline
\end{tabular}

\subsubsection{Uji Multikolinearitas}

Berdasarkan hasil uji multikolinearitas terlihat bahwa nilai tolerance dari variabel pengendalian internal sebesar 0,9 dan nilai tolerance dari variabel komitmen organisasi sebesar 0,9 kedua variabel sudahlebih besar dari 0,1 . Kemudian nilai VIF kedua variabel lebih kecil dari 10. Dapat disimpulkan bahwa tidak ada multikolinearitas antara variabel independen yang digunakan

\begin{tabular}{|l|r|r|}
\hline \multirow{2}{*}{ Variabel } & \multicolumn{2}{|c|}{ Collinearity Statistics } \\
\cline { 2 - 3 } & Tolerance & VIF \\
\hline Pengendalizn Internal & 0.919 & 1.088 \\
\hline Komitmen Organisasi & 0.919 & 1.088 \\
\hline
\end{tabular}

\subsubsection{Uji Heteroskedastisitas}

Hasil uji heteroskedastisitas menunjukkan bahwa nilai sig. variabel pengendalian internal adalah sebesar 0,662>0,05 yang artinya data terbebas dari heteroskedastisitas. Variabel komitmen organisasi adalah sebesar $0,302>0,05$ yang artinya data terbebas dari heteroskedastisitas. Berdasarkan kriteria uji heteroskedastisitas dapat disimpulkan bahwa tidak ada heteroskedastisitas pada model regresi.

\begin{tabular}{|c|r|r|r|r|r|}
\hline \multirow{2}{*}{ Model } & \multicolumn{2}{|c|}{$\begin{array}{c}\text { Unstandardized } \\
\text { Coefficients }\end{array}$} & $\begin{array}{r}\text { Standardized } \\
\text { Coefficients }\end{array}$ & \multirow{2}{*}{$\mathrm{t}$} & Sig. \\
\cline { 2 - 4 } & $\mathrm{B}$ & \multicolumn{1}{|c|}{$\begin{array}{c}\text { Std. } \\
\text { Error }\end{array}$} & \multicolumn{1}{|c|}{ Beta } & & \\
\hline $\begin{array}{l}\text { (Constant) } \\
\begin{array}{l}\text { Pengendalian } \\
\text { Internal }\end{array}\end{array}$ & 1.123 & 2.639 & & .425 & .673 \\
$\begin{array}{l}\text { Komitmen } \\
\text { Organisasi }\end{array}$ & -.047 & .108 & -.080 & -.441 & .662 \\
\hline
\end{tabular}

\subsubsection{Uji Regresi Linier Berganda}

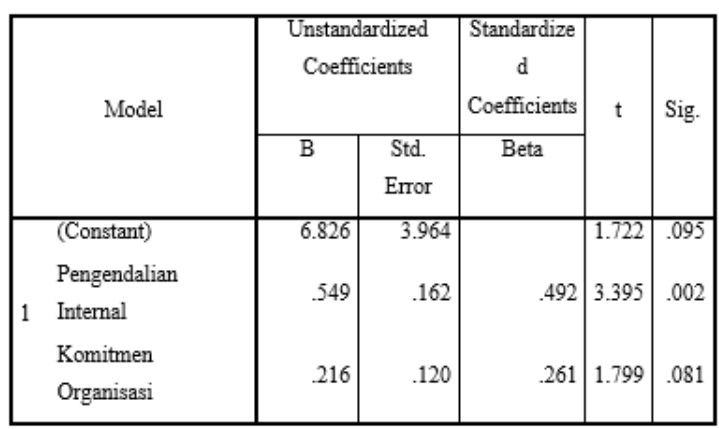

Kualitas Pelaporan Keuangan $=6,826+0,549$

$$
\mathrm{X}_{1}+0,216 \mathrm{X}_{2}
$$

Persamaan tersebut dapat diartikan: 
a. $=6,826:$ artinya jika Pengendalian Internaldan

Komitmen

Organisasibernilai $\quad 0, \quad$ maka

Kualitas Pelaporan Keuanganakan bernilai 6,826 .

$\mathrm{b}_{1}=0,549:$ artinya jika Pengendalian Internalmeningkat sebesar satu satuan, maka Kualitas Pelaporan Keuanganakannaik sebesar0,549. $\mathrm{b}_{2}=0,216:$ artinya jika Komitmen Organisasimeningkat sebesar satu satuan, maka Kualitas Pelaporan Keuanganakannaik sebesar0,216.

\subsection{Uji Hipotesis}

\subsubsection{Uji t}

\begin{tabular}{|c|c|c|c|c|c|}
\hline \multirow[t]{2}{*}{ Model } & \multicolumn{2}{|c|}{$\begin{array}{c}\text { Unstandardized } \\
\text { Coefficients }\end{array}$} & \multirow{2}{*}{$\begin{array}{c}\begin{array}{c}\text { Standardized } \\
\text { Coefficients }\end{array} \\
\text { Beta }\end{array}$} & \multirow[t]{2}{*}{$\mathrm{t}$} & \multirow[t]{2}{*}{ Sig. } \\
\hline & B & Std. Error & & & \\
\hline (Constant) & 6.826 & 3.964 & & 1.722 & .095 \\
\hline 1 Pengendalian Internal & .549 & .162 & .492 & 3.395 & .002 \\
\hline Komitmen Organisasi & .216 & .120 & .261 & 1.799 & .081 \\
\hline
\end{tabular}

Hasil pengujian hipotesis secara parsial adalah sebagai berikut:

1. Nilai sig. variabel Pengendalian Internal adalah sebesar 0,002 lebih kecil dari tingkat signifikasi penelitian sebesar 0,05. Maka dapat disimpulkan terdapat pengaruh pengendalian internal terhadap kualitas pelaporan keuangan.

2. Nilai sig. variabel Komitmen Organisasi adalah sebesar 0,081 lebih besar dari tingkat signifikasi penelitian sebesar 0,05. Maka dapat disimpulkan tidak terdapat pengaruh komitmen organisasi terhadap kualitas pelaporan keuangan.

\subsubsection{Koefisien Determinasi}

\begin{tabular}{|c|c|c|c|c|}
\hline Model & $R$ & R Square & $\begin{array}{c}\text { Adjusted R } \\
\text { Square }\end{array}$ & Std. Error of the Estimate \\
\hline 1 & $.619^{\mathbf{2}}$ & .383 & .344 & 2.40541 \\
\hline
\end{tabular}

Hasil koefisien determinasi menunjukkan nilai Adjusted $R$ Square sebesar 0,344. Dapat diartikan bahwa variabel Pengendalian Internal dan Komitmen Organisasimampu menjelaskan Kualitas Pelaporan Keuangan sebesar $34,4 \%$ dan sisanya $65,6 \%$ dijelaskan oleh faktor lain yang tidak diteliti.

\subsection{Pembahasan}

\subsubsection{Pengendalian Internal}

Berdasarkan hasil analisis regresi berganda diketahui bahwa koefisien regresi variabel Pengendalian Internal menunjukkan arah hubungan positif terhadap Kualitas Pelaporan Keuangan.

Pada pengujian hipotesis secara parsial, diketahui bahwa variabel Pengendalian Internal menunjukkan pengaruh terhadap Kualitas Pelaporan Keuangan dengan signifikansi sebesar 0,002 lebih kecil dari tingkat signifikansi penelitian sebesar 0,05. Hasil penelitian ini sejalan dengan penelitian Warih Komarasari (2017), Faristina Rosalin \& Warsito Kawedar (2011), dan Joe Sugandiet al (2013) yang menyatakan bahwa pengendalian internalberpengaruh terhadap kualitas pelaporan keuangan.

Pada dimensi keandalan terhadap laporan keuangan termasuk dalam kategori cukup memadai dengan melihat bahwa telah mempertimbangkan aspek pencatatan dan dokumentasi, dimana pada organisasi ini 
diketahui dokumentasi terhadap transaksi ataupun kejadian penting telah dilakukan secara cukup lengkap dan akurat sehingga hal ini cukup memfasilitasi penelusuran transaksi. Selanjutnya diketahui juga bahwa sistem penggajian telah cukup memadai dan perlu memperhatikan insentif khusus yang dapat mendorong pegawai bekerja secara maksimal. Untuk pemanfaatan berbagai bentuk sarana komunikasi sudah ada namun belum total diperhatikan. Para karyawan sebaiknya diberikan pemahaman bahwa tugas mereka dapat mempengaruhi tugas pegawai lainnya, dengan dibangun saluran komunikasi yang lebih memadai akan mempermudah setiap orang untuk melaporkan adanya penyimpangan dan menyampaikan saran-saran perbaikan, serta memadainya komunikasi antar unit dalam organisasi.

Pada dimensi efektivitas dan efisiensi operasi termasuk dalam kategori cukup karena telah memperhatikan adanya kelemahan pada aktivitas pengendalian terutama disebabkan pada aspek pengendalian fisik asset. Diketahui juga telah memperhatikan aspek analisis risiko dan penyebabnya namun belum sampai total menghilangkan risiko pada organisasinya.

Pada dimensi kepatuhan terhadap hukum yang berlaku tindakan disiplin atau sanksi atas pelanggaran telah ditegakkan dengan harapan memberikan efek jera dan meminimalisir kejadian berulang oleh pihak yang sama. Untuk pemberian wewenang dan tanggungjawab telah sepenuhnya memahami tanggungjawab pengendalian dan pengawasan yang dimiliki, serta struktur organisasi yang dimiliki oleh organisasi telah berjalan karena telah memegang tanggungjawab pengendalian dan pengawasan yang lengkap.

Pengendalian internal yang memadai akan mempengaruhi kualitas pelaporan keuangan. Hal ini berarti jika implementasi untuk menyusun laporan keuangan tidak didukung oleh sistem pengendalian intern yang baik, maka akan terjadi ketidakefisienan di dalam pelaporan keuangan. Untuk terwujudnya pelaporan keuangan yang berkualitas dibutuhkan perhatian terhadap pengendalian internal yang tepat guna bahkan sistem pengendalian intern akan sangat memadai bila pengendalian tersebut menyatu dengan infrastuktur dan merupakan bagian penting dari organisasi.

\subsubsection{Komitmen Organisasi}

Berdasarkan penelitian variabel Komitmen Organisasi tidak berpengaruh terhadap Kualitas Pelaporan Keuangan dengan signifikansi sebesar 0,081 lebih besar dari tingkat signifikansi penelitian yaitu sebesar 0,05. Hasil penelitian ini didukung oleh penelitian Khusnah (2015) yang memperoleh hasil bahwa komitmen organisasi tidak berpengaruh terhadap Kualitas Pelaporan Keuangan pada SKPD Pemerintah Kabupaten Malang.

Berdasarkan wawancara dengan responden, variabel komitmen organisasi tidak berpengaruh disebabkan oleh beberapa hal :

1. Berdasarkan indikator keterikatan secara emosional, responden merasa menjadi 
bagian dari organisasi dimana tempat mereka bekerja karena responden menjadi bagian yang cukup penting di dalam organisasi.

2. Berdasarkan indikator menerima dengan positif dan setuju dengan tujuan dan nilai organisasi, responden mendukung tujuan organisasi tetapi tujuan responden dengan organisasi kurang sejalan dikarenakan tujuan organisasi yang lebih rumit.

3. Berdasarkan indikator nilai ekonomi jika meninggalkan perusahaan, bagi responden wanita tunjangan/gaji yang diberikan oleh perusahaan cukup menjamin untuk masa depan tetapi hal itu berbeda bagi pria, tunjangan/gaji dirasa kurang cukup karena biaya hidup yang semakin besar dan banyaknya tuntutan kebutuhan yang ada. Sehingga tunjangan/gaji yang diberikan oleh organisasi hanya cukup untuk kebutuhan sehari-hari dan tidak bisa untuk berinvestasi kedepannya.

4. Berdasarkan indikator merasa berkewajiban melanjutkan pekerjaan, responden tetap bertahan bekerja di organisasi dikarenakan responden tidak mau berpindahpindah tempat kerja dan juga lingkungan pertemanan yang mendukung sehingga responden merasa nyaman bekerja di organisasi.

Ada beberapa faktor penentu kualitas pelaporan keuangan yang salah satunya adalah komitmen organisasional yang diartikan sebagai keterikatan seseorang untuk selalu bekerja pada sebuah perusahaan. Fenomena buruknya laporan keuangan di Kementrian/Lembaga pemerintahan seperti yang dikatakan BPK (2015) ini disebabkan karena belasan ribu permasalahan dalam pengelolaan keuangan pemerintah. Sementara itu, berdasarkan jenis pemeriksaannya yang terdiri atas 607 pemeriksaan keuangan, 5 pemeriksaan kinerja, dan 54 pemeriksaan dengan tujuan tertentu. Dari pemeriksaan tersebut ditemukan sebanyak 10.154 temuan yang memuat 15.434 permasalahan yang meliputi 7.890 atau 51,12 persen permasalahan ketidakpatuhan terhadap ketentuan peraturan perundang-undangan senilai $\mathrm{Rp} 33,46$ triliun dan 7.544 atau 48,88 persen permasalahan kelemahan sistem pengendalian intern. Fenomena tersebut telah menunjukkan rendahnya komitmen pimpinan akan menyebabkan sulitnya mencapai kualitas pelaporan keuangan.

\section{SIMPULAN DAN SARAN}

\subsection{Simpulan}

Berdasarkan hasil pengumpulan dan pengolahan data yang telah dilakukan, maka dapat disimpulkan:

1. Terdapat pengaruh pengendalian internal terhadap kualitas pelaporan keuangan. Hasil ini terlihat berdasarkan fenomena bahwa pengendalian internal yang lemah menyebabkan laporan keuangan menjadi buruk. Semakin tinggi pengendalian intenal maka semakin tinggi juga kualitas pelaporan keuangan. Untuk 
meningkatkan pengendalian internal maka perusahaan perlu untuk meningkatkan sistem pengendalian internal, efisiensi dan efektivitas operasi serta meningkatkan kepatuhan terhadap hukum dan peraturan yang berlaku.

2. Tidak terdapat pengaruh komitmen organisasi terhadap kualitas pelaporan keuangan. Hal ini dapat dilihat jika komitmen organisasi karyawan tidak mempengaruhi kualitas pelaporan keuangan karena rendahnya komitmen karyawan maka kualitas pelaporan keuangan tidak sesuai dengan peraturan yang berlaku. Untuk meningkatkan komitmen organisasi terhadap kualitas pelaporan keuangan, diperlukan sumber daya manusia yang sadar akan keterlibatannya terhadap perusahaan dan memiliki keterikatan secara emosional

\subsection{Saran}

Berdasarkan simpulan yang didapatkan pada penelitian ini, maka beberapa saran yang dapat penulis berikan, antara lain:

1. Pengendalian internal berpengaruh secara signifikan terhadap kualitas pelaporan keuangan, maka bagi PT X dan PT Gistex Textile Division harus lebih mendorong karyawan untuk lebih efektif dan efisien dalam memproses laporan keuangan dan menodorong karyawan untuk lebih terliti dalam memproses setiap informasi agar tidak terjadi kesalahan dan dapat menghasilkan laporan keuangan yang andal.
2. Komitmen organisasi tidak berpengaruh terhadap kualitas pelaporan keuangan, maka manajemen PT X dan PT Gistex Tekstil Division harus lebih meningkatkan komitmen karyawan terhadap organisasi agar karyawan merasa memilki keterikatan emosional dengan tempat kerja sehingga karyawan dapat menjalankan pekerjaannya dengan baik dan dapat menghasilkan laporan keuangan yang andal.

3. Penelitian ini belum mengungkap seluruh variabel yang dapat mempengaruhi kualitas pelaporan keuangan yang berdampak terhadap kualitas laporan keuangan, maka peneliti lain diharapkan meneliti variabel lainnya seperti e-commerce, motivasi, komitmen manajemen dan lain-lain. Setiap item pernyataan dalam kuesioner yang dirancang harus mampu menangkap realita yang terjadi dalam kegiatan operasional yang dihadapi para responden sehari-hari. Hal ini untuk mengantisipasi perbedaan yang terjadi antara fenomena dan hasil skor rata-rata responden yang menjadi sampel mayoritas berada dalam kategori baik karena kuesioner yang dirancang belum mampu menangkap realita yang dihadapi responden telah sejalan dengan fenomena yang ada. Untuk menambah jumlah responden yang mungkin dapat berpartisipasi, diharapkan peneliti berikutnya dapat mengambil unit analisis selain organisasi dalam perusahaan manufaktur mengingat padatnya 
aktivitas sehari-hari responden yang

bekerja pada organisasi tersebut.

\section{Daftar Pustaka}

Anwar Nasution. 2009. Benang Kusut Laporan Keuangan Daerah Akuntan Indonesia. Majalah Akuntan Indonesia edisi no. 18/ Juli/2009, Hal 17

Baldwin., Bommer.,\&Rubin.(2013). Managing Organizational Behavior. Second edition.McGraw-Hill education. America, New York.

Budi Mulya. 2010. Bank Dituntut Lebih Transparan dan Jujur Laporkan Neraca Keuangan.Kontan.Co.Id/News 29/4/2010

Dodopo, Y., Sondakh, J.J., \& Tinangon, J.J. (2017). Pengaruh Komitmen Organisasi, Pengendalian Intern Akuntansi, Peran Internal Audit, Pendidikan, Dan Kualitas Pelatihan Terhadap Keterandalan Laporan Keuangan Pada SKPD Pemerintah Kabupaten Halmahera Utara. Diperoleh dari https://ejournal.unsrat.ac.id/index.php/goodwi 11/article/view/15306.

Darwanis \& Mahyani, D.D. (2009). Pengaruh Kapasitas Sumber Daya Manusia, Pemanfaatan Teknologi Informasi Dan Pengendalian Intern Akuntansi Terhadap Keterandalan Pelaporan Keuangan Pemerintah Daerah. Jurnal Telaah \& Riset Akuntansi Vol. 2.No. 2 Juli 2009 Hal.133151.

Firmansyah, Teguh. (2016, 9 juni).Pencatatan Keuangan Buruk, Fitra : Negara Rugi Rp 221,8 Triliun.Republika.co.id. Diperoleh dari http://nasional.republika.co.id/berita/nasional/ umum/16/06/09/o8hv0a377pencatatankeuangan-buruk-fitra-negara-rugi-rp-2218triliun. 
Gamawan Fauzi. 2012. Target 50\% Daerah Wtp Pada Tahun 2014 Sulit Dicapai. Harian Kompas, Rabu, 25 Juli, Hal 4.

Greenberg, Jerald. (2011). Behavior in

Organization, 10th edition. London, UK: Pearson Education.

Harrer, Julie. (2008). Internal Control Strategies:

A Mid to Small Business Guide. CFA Institute

Investment Series [e-book]. Diperoleh dari https://libgen.pw/.

Hendrisman

Rahim, 2013. http://keuangan.kontan.co.id/news/lapo ran-kinerja-asuransi-terkendalaifrs/Jum'at, 22 Maret, 2013

Hilton, Ronald, W., Michael W. Maher, dan Frank H. Selto. Costs Management, Strategis for Business Decision. International Edition, McGraw-Hill Companies, Inc.

Ikatan Akuntan Indonesia dalam Standar

Profesional Akuntan Publik seksi 319 no 69, 2001:319.1.

Ikatan Akuntan Indonesia.(2015). Standar Akuntansi Keuangan. Jakarta:IAI.

Jogiyanto.(2007). Metodologi Penelitian Bisnis

Salah Kaprah dan Pengalaman-Pengalaman.

Yogyakarta: BPFE.

Khusnah, Lailatul. (2015). Pengaruh Standar Akuntansi, Audit Intern, dan Komitmen Organisasi terhadap Kualitas Pelaporan Keuangan dengan Sistem Pengendalian Intern sebagai Variabel Intervening pada SKPD Pemeritah Kabupaten Malang.Diperoleh dari http://repository.unair.ac.id/33631/

Kieso, Donald E.. 2012. Intermediate Accounting. $14^{\text {th }}$ Edition. UK: John Willey and Sons, Inc.

Komarasari, W.(2017). Pengaruh Kapasitas

Sumber Daya Manusia, Pemanfaatan

Teknologi Informasi dan Pengendalian Intern terhadap Keterandalan Pelaporan Keuangan (Skripsi, Universitas PGRI Yogyakarta). Diperoleh dari http://repository.upy.ac.id/1277/1/Artikel.pdf. Kreitner, R.\& Kinicki, A. (2007).Organizational Behavior.7th ed. McGraw-Hill Inc. New York.

Luthans,F. 2011. Organizational Behavior : An Evidence-Based Approach. 12th Edition. New York: McGraw-Hill/Irwin

Moeller, R. R. (2008). Sarbanes-Oxley Internal Controls: Effective Auditing with AS5, CobiT, and ITIL. Hoboken: John Wiley \& Sons, Inc. [e-book]. Diperoleh dari https://libgen.pw/.

Perwitasari, Puspa. (2015, 5 Oktober).BPK:

Belasan Ribu Masalah di Laporan Keuangan Pemerintah.Viva.co.id. Diperoleh dari http://www.viva.co.id/berita/bisnis/683068bpk--belasan-ribu-masalah-di-laporankeuangan-pemerintah.

Pratomo, Harwanto Bimo (2013, 11 februari).Menkeu: Kualitas Laporan Keuangan $\quad 10 \quad$ Kementrian Buruk.Merdeka.com. Diperoleh dari https://www.merdeka.com/uang/menkeukualitas-laporan-keuangan-10-kementerianburuk.html.

Robbins, S.P., \& Judge, T.A. (2007).Organizational Behavior Twelfth Edition. New Jersey: Pearson Education, Inc. Robinson, T. R., Henry, E., Pirie, W. L., Broihahn,M. A., Cope, A. T.(2015).International Financial Statement Analysis, Third Edition. New Jersey: John Wiley \& Sons, Inc.

Rosalin, F.\& Kawedar, W. (2011). Faktor-faktor yang Mempengaruhi Keandalan dan 
JAFTA匹 Vol. 1 Nomor 1, Mei (2019)

Timeliness Pelaporan Keuangan Badan

Layanan Umum.Diperoleh dari

http://eprints.undip.ac.id/29439/.

Sigit Pramono. 2010. Bank Indonesia Pertimbangkan Ancaman Sanksi Window Dressing.Melalui,http://www.tempo.co/rea d/news/2010/04/28/087243927/BankIndonesia-Pertimbangkan-AncamanSanksi-Window Dressing [28/04/2010]

Sonnelitter, Robert J. (2008). Sox 404 For Small Publicly Held Companies [e-book]. Diperoleh dari

https://books.google.co.id/books/about/SOX 404_for_Small_Publicly_Held_Companie.ht $\mathrm{ml}$ ?id=7tlyDb3YDoEC\&redir_esc=y.

Sugandi, J., Desmiyawati.,\& Hanif, R.A.(2013).

Pengaruh Kapasitas Sumber Daya Manusia, Pemanfaatan Teknologi Informasi, Pengendalian Intern Akuntansi, dan Komitmen Organisasi Terhadap Keterandalan Pelaporan Keuangan Pemerintah Daerah (Survei Pada SKPD se-Kabupaten Kuansing). Jurnal Akuntansi. FE: Universitas RIAU. Diperoleh dari https://jom.unri.ac.id/index.php/JOMFEKON/ article/view/3035.

Suliyanto.(2009). Metode Riset Bisnis.

Yogyakarta: CV Andi Offset

Susanto, A. 2008. Sistem Informasi Akuntansi: Struktur Pengendalian Risiko Pengembangan. Edisi Perdana: Lingga Jaya

Suwardjono. (2005). Teori Akuntansi: Perekayasaan Pelaporan Keuangan, Edisi Ketiga. BPFE- Yogyakarta.

Tunggal, A. W.(2010). Dasar-Dasar Audit Internal. Jakarta: HARVARINDO.
Wiley.(2015). Wiley Study Guide for 2015 Level II CFA Exam Volume 1. New Jersey: John Wiley \& Sons, Inc. 